\title{
Retechnologization of biological sewage water treatment facilities using mathematical modelling
}

\author{
Liliya Khisameeva ${ }^{1 *[0000-0001-9873-4886]}$, Runar Abitov ${ }^{1[0000-0001-6138-6419]}$, and Ramis \\ Alimov ${ }^{10000-0003-0474-3488]}$ \\ ${ }^{1}$ Kazan State University of Architecture and Engineering, 420043, Zelenaya st., Kazan, Russia
}

\begin{abstract}
The efficiency of sewage treatment plants is an urgent problem of the designed and operating stations. In modern conditions, efficiency is understood as the operation of facilities in which operating costs are minimized, facilities provide standard cleaning, and the company implements measures to modernize and improve energy efficiency and trouble-free operation. The article deals with the comparative analysis and selection of the most optimal scheme of biological sewage water treatment of existing sewage water treatment plants. The indicators of the efficiency of functioning and permissible loads on treatment facilities in the design of aeration tanks for biological sewage water treatment are determined. The results served as the basis for the creation of a mathematical model, with the help of which it is possible to calculate the parameters of the biological treatment system and optimize the process of biological sewage water treatment at existing treatment facilities. Mathematical modeling allows you to reduce the cost of designing and operating treatment facilities, to guarantee the degree of treatment in accordance with the requirements and standards for the discharge of treated sewage water into a reservoir for fisheries purposes.
\end{abstract}

Keywords: sewage water, eutrophication, biological treatment, biogenic elements, modeling, aeration tank, technological scheme.

\section{Introduction}

The main cause of pollution of water bodies with biogenic elements that violate the stability of the biosystem is the discharge of urban and industrial sewage water. Scientists from different countries of the world have been solving the problems of high-quality sewage water treatment to prevent eutrophication of water bodies for many years [1-4]. At the end of the twentieth century, our country tightened the standards for the discharge of pollutants into water bodies, introdalde compounds from sewage water based on the recommendations of research organizations. Since 2012, the updated Construction Norms and Regulations (SNiP) (SP 32.13330.2012 «Sewerage. External networks and structures») allowed for the calculation of structures

*Corresponding author: khisameeva_liliya@mail.ru 
with biological removal of nitrogen and phosphorus to use any, including foreign calculation methods. The degree of treatment of sewage water discharged into water bodies must meet the requirements of the current legislation in the field of environmental protection [5].

Traditional biological sewage water treatment allows to remove the bulk of organic pollutants, to oxidize ammonium nitrogen to nitrate, but cannot provide a sufficient depth of removal of nitrogen and phosphorus compounds [6-8]. The issue of removal of nutrients is a priority in improving the quality of treated sewage water before discharge into fisheries reservoirs. Biogenic elements - elements that are constantly included in the composition of organisms and perform certain biological functions. The most important biogenic elements are oxygen, carbon, hydrogen, nitrogen, phosphorus, sulfur, calcium, potassium, sodium, and chlorine. Nitrogen and phosphorus are one of the main components of sewage water, the presence of which in municipal or close to them in the composition of household water is constantly recorded. Nitrogen in sewage water can be represented by several compounds: ammonium nitrogen $\left(\mathrm{NH}_{4}^{-}\right)$, nitrite nitrogen $\left(\mathrm{NO}_{2}^{-}\right)$, nitrate nitrogen $\left(\mathrm{NO}_{3}^{-}\right)$, organic nitrogen (as part of organic compounds). Phosphorus in sewage water is found in organic compounds (organic phosphorus), polyphosphates $\left(\mathrm{P}_{2} \mathrm{O}_{5}\right)$, and orthophosphates $\left(\mathrm{PO}_{4}\right)$.

The biological method of deep removal of biogenic substances from sewage water makes it possible to achieve the total phosphorus content in treated waters of $1.0 \ldots 1.5$ $\mathrm{mg} / \mathrm{dm}^{3}$, and the total nitrogen content of $8 \ldots 10 \mathrm{mg} / \mathrm{dm}^{3}$ (including protein, ammonium, nitrite and nitrate) in real biological treatment facilities. The biological method of phosphorus removal makes it possible to achieve a high quality of phosphorus treatment, but this process is very sensitive to the current quality of sewage water received for treatment and requires highly qualified technologists-operators [6-10].

Biological removal of nitrogen from sewage water consists in the following processes: ammonification, in the decomposition of organic nitrogen-containing compounds to nonorganic ammonium; nitrification, in the two-stage oxidation of ammonium nitrogen compounds first to nitrites, then to nitrates; denitrification - in the bacterial reduction of nitrate nitrogen to molecular, accompanied by the oxidation of organic substances. At the same time, oxygen is saved, since some organic substances are not oxidized by dissolved oxygen, but by the oxygen of nitrates. To ensure the intensive course of nitrification, denitrification and biological dephosphation processes, biological treatment facilities are divided into zones with different levels of aeration - aerobic, anoxic and aerobic. Biological treatment of sewage water from nitrogen and phosphorus, based on the processes of ammonification, nitri-denitrification and dephosphotation, is currently recognized as the most economical and environmentally friendly, due to its high efficiency and low consumption [11].

The complexity of the implementation of the developed methods of urban sewage water treatment is that most of the treatment facilities were built in the 80-90s of the last century and currently need reconstruction, as they are morally and physically outdated and do not meet modern requirements. The amount of financial resources required for reconstruction is considerable, and the possibilities are limited. Therefore, there is always a question of the need for reconstruction of sewage water treatment facilities, with minimal financial investments, maximum use of existing facilities and obtaining the required standard quality of sewage water treatment $[12,13]$.

The aim of this study is to define ways to improve the efficiency of nitrogen removal and phosphorus in biological processes of denitrification and deflation. At the same time, the tasks of minimizing capital investment in facilities and the use of modern technologies of sewage water treatment for nitrogen and phosphorus removal using mathematical modelling techniques in the design of new and reconstruction of existing sewage treatment plants are being solved. The interest in modeling sewage water treatment facilities is explained by the fact that the design, implementation and debugging of new technological solutions is impossible without careful preliminary technological and engineering 
calculations. The use of mathematical models makes it possible to significantly reduce the time in the design and operation of sewage water treatment facilities. The software provides a fairly complete picture of the object's behavior under dynamic conditions, i.e., over time. At the same time, it is possible to consider the state of objects in static conditions, taking into account the analysis of other variables, such as the length or depth of structures, which allows us to take into account the hydrodynamic parameters of structures [14].

\section{Methods}

The biological treatment facilities of Almetyevsk were built in 1967. The design capacity is 40 thousand $\mathrm{m}^{3} /$ day, the actual capacity is 38 thousand $\mathrm{m}^{3} /$ day. The sewage water received for treatment is a mixture of industrial and domestic sewage water. The amount of industrial sewage water in the total volume of sewage water inflow is not significant. Sewage water is treated mechanically and biologically. Mechanical cleaning is carried out in the grate building, in horizontal sand traps and primary sedimentation tanks of the radial type. Further, the sewage water enters the aeration tanks, where organic matter is oxidized and settled in secondary sedimentation tanks. The clarified water is chlorinated in the contact tank and discharged into the Stepnoy Zai River via a scattering outlet. Sludge from secondary sedimentation tanks enters the sludge beds.

The flow of sewage water to the treatment facilities is characterized by unevenness during the day and seasonal fluctuations $[8,15]$.

During the operation of the treatment facilities, laboratory tests revealed that the quality of sewage water treatment does not meet the regulatory values, exceeds the maximum permissible concentrations (MPC) for a fishing reservoir (Table 1).

Table 1a. Data on the composition of incoming sewage water.

\begin{tabular}{|c|c|c|c|c|c|c|c|}
\hline \multirow{3}{*}{ Name } & \multirow{3}{*}{$\begin{array}{l}\text { Unit of } \\
\text { measur } \\
\text { ement }\end{array}$} & \multicolumn{6}{|c|}{ Incoming water } \\
\hline & & \multicolumn{3}{|c|}{2014} & \multicolumn{3}{|c|}{2015} \\
\hline & & $\min$ & med & $\min$ & med & $\min$ & med \\
\hline Ammonium ion & $\mathrm{mg} / \mathrm{l}$ & 73.5 & 77.8 & 80.0 & 59.2 & 68.4 & 75.0 \\
\hline $\mathrm{BOD}_{5}$ & $\mathrm{mgO}_{2} / 1$ & 204.0 & 206.2 & 210.0 & 196.0 & 249.0 & 320.0 \\
\hline Suspended solids & $\mathrm{mg} / \mathrm{l}$ & 280.0 & 302.8 & 320.0 & 332.0 & 364.0 & 386.5 \\
\hline Hydrogen index & unit. & 7.7 & 7.7 & 7.8 & 7.8 & 7.8 & 7.9 \\
\hline Total iron & $\mathrm{mg} / \mathrm{l}$ & 1.1 & 1.71 & 2 & 1.039 & 2.39 & 3.95 \\
\hline Cadmium & $\mathrm{mg} / \mathrm{l}$ & $<0.01$ & $<0.01$ & $<0.01$ & $<0.01$ & $<0.01$ & $<0.01$ \\
\hline Manganese & $\mathrm{mg} / \mathrm{l}$ & 0.15 & 0.263 & 0.4 & 0.204 & 0.252 & 0.303 \\
\hline Copper & $\mathrm{mg} / \mathrm{l}$ & 0.01 & 0.012 & 0.03 & 0.017 & 0.021 & 0.027 \\
\hline petroleum products & $\mathrm{mg} / \mathrm{l}$ & 0.7 & 1.56 & 2.1 & 1.4 & 1.67 & 2.02 \\
\hline Nickel & $\mathrm{mg} / 1$ & $<0.02$ & $<0.02$ & $<0.02$ & $<0.02$ & $<0.02$ & $<0.02$ \\
\hline Nitrate ion & $\mathrm{mg} / \mathrm{l}$ & $<0.1$ & 0.35 & 0.5 & $<0.1$ & $<0.1$ & $<0.1$ \\
\hline Nitrite ion & $\mathrm{mg} / \mathrm{l}$ & $<0.02$ & $<0.02$ & $<0.02$ & $<0.02$ & $<0.02$ & $<0.02$ \\
\hline Anionic surfactants & $\mathrm{mg} / \mathrm{l}$ & 2 & 3.91 & 5.59 & 2 & 2.68 & 3.4 \\
\hline Sulfate ion & $\mathrm{mg} / \mathrm{l}$ & 55.2 & 74.8 & 100 & 87.7 & 108.2 & 121.4 \\
\hline Dry residue & $\mathrm{mg} / \mathrm{l}$ & 584 & 701 & 875 & 729 & 816.3 & 121.4 \\
\hline Phosphate ion & $\mathrm{mg} / \mathrm{l}$ & 6.15 & 11.93 & 19 & 14.3 & 28.8 & 47.68 \\
\hline Fluoride ion & $\mathrm{mg} / \mathrm{l}$ & 0.166 & 0.229 & 0.3 & 0.212 & 0.233 & 0.252 \\
\hline Chloride ion & $\mathrm{mg} / \mathrm{l}$ & 73 & 141 & 197 & 138.3 & 181.2 & 229.7 \\
\hline COD & $\mathrm{mgO}_{2} / 1$ & 434 & 466 & 516 & 284 & 397 & 456 \\
\hline Chrome 3+ & $\mathrm{mg} / \mathrm{l}$ & $<0.01$ & $<0.01$ & $<0.01$ & $<0.01$ & $<0.01$ & $<0.01$ \\
\hline Chrome $6+$ & $\mathrm{mg} / \mathrm{l}$ & $<0.01$ & $<0.01$ & $<0.01$ & $<0.01$ & $<0.01$ & $<0.01$ \\
\hline Zinc & $\mathrm{mg} / \mathrm{l}$ & 0.02 & 0.0218 & 0.028 & 0.019 & 0.028 & 0.044 \\
\hline
\end{tabular}


Table 1b. Data on the composition of incoming sewage water.

\begin{tabular}{|c|c|c|c|c|c|c|c|}
\hline \multirow{3}{*}{ Name } & \multirow{3}{*}{$\begin{array}{l}\text { Unit of } \\
\text { measur } \\
\text { ement }\end{array}$} & \multicolumn{6}{|c|}{ Incoming water } \\
\hline & & \multicolumn{3}{|c|}{2016} & \multicolumn{3}{|c|}{ For the first half of } \\
\hline & & $\min$ & med & $\min$ & med & $\min$ & med \\
\hline Ammonium ion & $\mathrm{mg} / \mathrm{l}$ & 54.3 & 79.1 & 54.3 & 79.1 & 54.3 & 79.1 \\
\hline $\mathrm{BOD}_{5}$ & $\mathrm{mgO}_{2} / 1$ & 188.0 & 263.7 & 188.0 & 263.7 & 188.0 & 263.7 \\
\hline Suspended solids & $\mathrm{mg} / 1$ & 130.0 & 292.0 & 130.0 & 292.0 & 130.0 & 292.0 \\
\hline Hydrogen index & unit. & 7.8 & 7.8 & 7.8 & 7.8 & 7.8 & 7.8 \\
\hline Total iron & $\mathrm{mg} / \mathrm{l}$ & 1.17 & 2.04 & 1.17 & 2.04 & 1.17 & 2.04 \\
\hline Cadmium & $\mathrm{mg} / \mathrm{l}$ & 0.0046 & 0.0048 & 0.004 & 0.004 & 0.004 & 0.004 \\
\hline Manganese & $\mathrm{mg} / \mathrm{l}$ & 0.162 & 0.181 & 0.162 & 0.181 & 0.162 & 0.181 \\
\hline Copper & $\mathrm{mg} / \mathrm{l}$ & 0.0157 & 0.0212 & 0.015 & 0.021 & 0.015 & 0.021 \\
\hline petroleum products & $\mathrm{mg} / \mathrm{l}$ & 1.14 & 1.88 & 1.14 & 1.88 & 1.14 & 1.88 \\
\hline Nickel & $\mathrm{mg} / \mathrm{l}$ & 0.0073 & 0.0083 & 0.007 & 0.008 & 0.007 & 0.008 \\
\hline Nitrate ion & $\mathrm{mg} / \mathrm{l}$ & $<0.1$ & 0.214 & $<0.1$ & 0.214 & $<0.1$ & 0.214 \\
\hline Nitrite ion & $\mathrm{mg} / \mathrm{l}$ & $<0.02$ & $<0.02$ & $<0.02$ & $<0.02$ & $<0.02$ & $<0.02$ \\
\hline Anionic surfactants & $\mathrm{mg} / 1$ & 1.3 & 1.94 & 1.3 & 1.94 & 1.3 & 1.94 \\
\hline Sulfate ion & $\mathrm{mg} / \mathrm{l}$ & 79.4 & 113.5 & 79.4 & 113.5 & 79.4 & 113.5 \\
\hline Dry residue & $\mathrm{mg} / \mathrm{l}$ & 79.4 & 113.5 & 79.4 & 113.5 & 79.4 & 113.5 \\
\hline Phosphate ion & $\mathrm{mg} / \mathrm{l}$ & 4.88 & 16.46 & 4.88 & 16.46 & 4.88 & 16.46 \\
\hline Fluoride ion & $\mathrm{mg} / \mathrm{l}$ & 0.183 & 0.398 & 0.183 & 0.398 & 0.183 & 0.398 \\
\hline Chloride ion & $\mathrm{mg} / \mathrm{l}$ & 116.2 & 210.3 & 116.2 & 210.3 & 116.2 & 210.3 \\
\hline COD & $\mathrm{mgO}_{2} / 1$ & 294.4 & 353.1 & 294.4 & 353.1 & 294.4 & 353.1 \\
\hline Chrome 3+ & $\mathrm{mg} / \mathrm{l}$ & $<0.01$ & $<0.01$ & $<0.01$ & $<0.01$ & $<0.01$ & $<0.01$ \\
\hline Chrome 6+ & $\mathrm{mg} / \mathrm{l}$ & $<0.01$ & $<0.01$ & $<0.01$ & $<0.01$ & $<0.01$ & $<0.01$ \\
\hline Zinc & $\mathrm{mg} / \mathrm{l}$ & 0.02 & 0.0252 & 0.02 & 0.025 & 0.02 & 0.025 \\
\hline
\end{tabular}

The analysis of the qualitative composition of the incoming sewage water showed that (Table 2.):

- the organic load in the incoming sewage water is moderately polluted;

- biogenic load in incoming sewage water: for ammonium nitrogen-highly polluted, for total phosphorus-medium polluted;

- there is an imbalance between nitrogen and phosphorus in the ratio of organic and biogenic substances;

- the average value of the suspended matter concentration is high enough to avoid primary sedimentation.

Table 2. The ratio of the main substances in the incoming sewage water.

\begin{tabular}{|c|c|c|}
\hline Ratio & Meaning & Charecteristics \\
\hline $\mathrm{COD} / \mathrm{BOD}_{\Pi}$ & 1.69 & Low \\
\hline $\mathrm{BOD}_{\Pi} / \mathrm{NH}_{4}$ & 4.50 & Middle \\
\hline $\mathrm{BOD}_{\Pi} / \mathrm{PPO}_{4}$ & 24.40 & High \\
\hline $\mathrm{BOD}_{\Pi}: \mathrm{N}: \mathrm{P}$ & $100.0: 13.4: 3.2$ & - \\
\hline
\end{tabular}

A survey of sewage facilities and analysis of laboratory data of sewage water after secondary biological treatment tanks (Table 3) and comparison with the current discharge requirements (Table 4) showed:

- nitrates do not exceed the current regulatory requirements, but this is not a result of complete oxidation of ammonium nitrogen, but is caused by the small capacity of biological treatment facilities; 
- ammonium nitrogen exceeds the discharge standard by more than $\mathrm{e}=89$ times, caused by a high load on the ingredient in the incoming water (including with return flows), and a short residence time of sewage water in biological treatment facilities;

- The ВODп еxceeds the discharge standard by more than $\mathrm{e}=20$ times, caused by the small capacity of the aeration tanks and the removal of colloidal under-oxidized substances;

- suspended substances exceed the discharge standard by more than $\varepsilon=7.1$ times, the removal of suspended substances is associated with the removal of colloidal under-oxidized substances;

-iron (ion) belongs to the group of heavy metals, is toxic and inert to biochemical oxidation, and its removal is carried out by precipitation and biosorption;

- petroleum products that exceed the permissible discharge by $\mathrm{e}=4$ times, which indicates insufficient technological efficiency of cleaning, removal is carried out due to chemical and biodegradation during biological cleaning, and to a lesser extent when surfacing at the stage of mechanical cleaning;

- nitrogen and phosphorus are biogenic elements, the purification efficiency is as follows:

- ammonium ion - excess of MPC in $\varepsilon=89$ times;

- nitrite ion-MPC excess in $\varepsilon=16$ times;

- nitrate ion-within the MPC;

- phosphates (ion) - excess of MPC in $\varepsilon=30$ times.

Methods of sewage water treatment from petroleum products and heavy metals are presented in the works $[16,17]$. The main technologies developed for the removal of phosphorus from sewage water can be classified into biological and chemical methods. The biological method often does not provide complete removal of phosphorus $[6,8]$. The authors also noted the disadvantages of biological sewage water treatment $[7,8]$, that the use of activated sludge gives high sediment production and low efficiency of removal of many organic and inorganic pollutants. In the article [8, 18], studies have been conducted that indicate that during biological sewage water treatment, phosphorus remains intact and needs further treatment. In $[8,19]$, a comparative evaluation of the reagents currently used for the extraction of phosphorus is given. Analysis of methods for the removal of phosphorus from sewage water has shown that the use of bioreagent sewage water treatment, in comparison with non-reagent methods of sewage water treatment, has advantages: the specific cost of treatment is lower to the standard indicators, the volume of tank facilities is significantly reduced during new construction, and it allows to achieve deep cleaning without reconstruction of existing treatment facilities [8].

Taking into account the strict requirements for the discharge of phosphates, a combined bio-reagent removal method should be provided, and the chemical stage of phosphorus removal should be provided at the post-treatment stage. 
Table 3a. Data on the composition of sewage water after treatment.

\begin{tabular}{|c|c|c|c|c|c|c|c|}
\hline \multirow{3}{*}{ Indicator name } & \multirow{3}{*}{$\begin{array}{c}\text { Unit of } \\
\text { measur } \\
\text { ement }\end{array}$} & \multicolumn{6}{|c|}{ Treated water } \\
\hline & & \multicolumn{3}{|c|}{2014} & \multicolumn{3}{|c|}{2015} \\
\hline & & $\min$ & med & $\min$ & med & $\min$ & med \\
\hline Ammonium ion & $\mathrm{mg} / \mathrm{l}$ & 42 & 52.1 & 58.1 & 14.1 & 40.2 & 64 \\
\hline $\mathrm{BOD}_{5}$ & $\mathrm{mgO}_{2} / \mathrm{l}$ & 8.1 & 40.5 & 71 & 31 & 76.1 & 120 \\
\hline Suspended solids & $\mathrm{mg} / \mathrm{l}$ & 13.6 & 215 & 410 & 21.5 & 60 & 96.5 \\
\hline Hydrogen index & unit. & 7.3 & 7.6 & 7.9 & 7.5 & 7.7 & 7.8 \\
\hline Total iron & $\mathrm{mg} / \mathrm{l}$ & 0.227 & 1 & 1.72 & 0.38 & 0.96 & 1.5 \\
\hline Cadmium & $\mathrm{mg} / \mathrm{l}$ & $<0.02$ & $<0.02$ & $<0.02$ & $<0.02$ & $<0.02$ & $<0.02$ \\
\hline Manganese & $\mathrm{mg} / \mathrm{l}$ & 0.168 & 0.228 & 0.288 & 0.114 & 0.156 & 0.197 \\
\hline Copper & $\mathrm{mg} / \mathrm{l}$ & $<0.001$ & 0.0125 & 0.025 & 0.023 & 0.012 & 0.020 \\
\hline Petroleum products & $\mathrm{mg} / \mathrm{l}$ & 0.115 & 0.4 & 0.683 & 0.055 & 0.248 & 0.439 \\
\hline Nickel & $\mathrm{mg} / \mathrm{l}$ & $<0.005$ & $<0.005$ & $<0.00$ & $<0.00$ & $<0.00$ & $<0.00$ \\
\hline Nitrate ion & $\mathrm{mg} / \mathrm{l}$ & $<0.1$ & 3.6 & 7.02 & 0.304 & 0.2 & $<0.1$ \\
\hline Nitrite ion & $\mathrm{mg} / \mathrm{l}$ & $<0.02$ & 1.5 & 2.9 & $<$ & 0.48 & 0.92 \\
\hline Anionic surfactants & $\mathrm{mg} / \mathrm{l}$ & 0.219 & 2.1 & 4 & 0.108 & 0.9 & 1.68 \\
\hline Sulfate ion & $\mathrm{mg} / \mathrm{l}$ & 58 & 83 & 107.9 & 73 & 117.5 & 160.3 \\
\hline Dry residue & $\mathrm{mg} / \mathrm{l}$ & 704 & 758 & 811 & 596 & 721 & 843 \\
\hline Phosphate ion & $\mathrm{mg} / \mathrm{l}$ & 1.54 & 9.3 & 17.04 & 0.25 & 6.7 & 13.1 \\
\hline Fluoride ion & $\mathrm{mg} / \mathrm{l}$ & 0.022 & 0.138 & 0.253 & $<0.01$ & 0.038 & 0.065 \\
\hline Chloride ion & $\mathrm{mg} / \mathrm{l}$ & 79 & 169 & 257.4 & 111.1 & 148.5 & 183.8 \\
\hline COD & $\mathrm{mgO}_{2} / \mathrm{l}$ & 24.3 & 59.1 & 92 & 31 & 107 & 183 \\
\hline Chrome 3+ & $\mathrm{mg} / \mathrm{l}$ & $<0.01$ & $<0.01$ & $<0.01$ & $<0.01$ & $<0.01$ & $<0.01$ \\
\hline Chrome $6+$ & $\mathrm{mg} / \mathrm{l}$ & $<0.01$ & $<0.01$ & $<0.01$ & $<0.01$ & $<0.01$ & $<0.01$ \\
\hline Zinc & $\mathrm{mg} / \mathrm{l}$ & 0.0114 & 0.015 & 0.018 & 0.009 & 0.016 & 0.022 \\
\hline
\end{tabular}

Table 3b. Data on the composition of sewage water after treatment.

\begin{tabular}{|c|c|c|c|c|c|c|c|}
\hline \multirow{3}{*}{ Indicator name } & \multirow{3}{*}{$\begin{array}{c}\text { Unit of } \\
\text { measure } \\
\text { ment }\end{array}$} & \multicolumn{6}{|c|}{ Treated water } \\
\hline & & \multicolumn{3}{|c|}{2016 г. } & \multicolumn{3}{|c|}{ For the first half of } \\
\hline & & $\min$ & med & $\min$ & med & $\min$ & med \\
\hline Ammonium ion & $\mathrm{mg} / \mathrm{l}$ & 23.4 & 45 & 23.4 & 45 & 23.4 & 45 \\
\hline $\mathrm{BOD}_{5}$ & $\mathrm{mgO}_{2} / 1$ & 9 & 38.1 & 9 & 38.1 & 9 & 38.1 \\
\hline Suspended solids & $\mathrm{mg} / \mathrm{l}$ & 12.5 & 65 & 12.5 & 65 & 12.5 & 65 \\
\hline Hydrogen index & unit. & 7.5 & 7.7 & 7.5 & 7.7 & 7.5 & 7.7 \\
\hline Total iron & $\mathrm{mg} / \mathrm{l}$ & 0.178 & 1.3 & 0.178 & 1.3 & 0.178 & 1.3 \\
\hline Cadmium & $\mathrm{mg} / \mathrm{l}$ & $<0.02$ & $<0.02$ & $<0.02$ & $<0.02$ & $<0.02$ & $<0$. \\
\hline Manganese & $\mathrm{mg} / \mathrm{l}$ & 0.11 & 0.17 & 0.11 & 0.17 & 0.11 & 0.17 \\
\hline Copper & $\mathrm{mg} / \mathrm{l}$ & $<0.001$ & 0.022 & $<$ & 0.022 & $<$ & 0.02 \\
\hline Petroleum products & $\mathrm{mg} / \mathrm{l}$ & 0.031 & 0.51 & 0.031 & 0.51 & 0.031 & 0.51 \\
\hline Nickel & $\mathrm{mg} / \mathrm{l}$ & $<0.005$ & $<0.005$ & $<0.005$ & $<0.005$ & $<0.005$ & $<0.0$ \\
\hline Nitrate ion & $\mathrm{mg} / \mathrm{l}$ & 0.94 & 19.7 & 0.94 & 19.7 & 0.94 & 19.7 \\
\hline Nitrite ion & $\mathrm{mg} / \mathrm{l}$ & 0.059 & 3.13 & 0.059 & 3.13 & 0.059 & 3.13 \\
\hline Anionic surfactants & $\mathrm{mg} / \mathrm{l}$ & 0.095 & 3.7 & 0.095 & 3.7 & 0.095 & 3.7 \\
\hline Sulfate ion & $\mathrm{mg} / \mathrm{l}$ & 82.5 & 134 & 82.5 & 134 & 82.5 & 134 \\
\hline Dry residue & $\mathrm{mg} / \mathrm{l}$ & 639 & 760 & 639 & 760 & 639 & 760 \\
\hline Phosphate ion & $\mathrm{mg} / \mathrm{l}$ & 0.146 & 7.2 & 0.146 & 7.2 & 0.146 & 7.2 \\
\hline Fluoride ion & $\mathrm{mg} / \mathrm{l}$ & 0.032 & 0.11 & 0.032 & 0.11 & 0.032 & 0.11 \\
\hline Chloride ion & $\mathrm{mg} / \mathrm{l}$ & 57 & 125 & 57 & 125 & 57 & 125 \\
\hline COD & $\mathrm{mgO}_{2} / 1$ & 42 & 81 & 42 & 81 & 42 & 81 \\
\hline Chrome 3+ & $\mathrm{mg} / \mathrm{l}$ & $<0.01$ & $<0.01$ & $<0.01$ & $<0.01$ & $<0.01$ & $<0$. \\
\hline Chrome 6+ & $\mathrm{mg} / \mathrm{l}$ & $<0.01$ & $<0.01$ & $<0.01$ & $<0.01$ & $<0.01$ & $<0$. \\
\hline Zinc & $\mathrm{mg} / \mathrm{l}$ & 0.0076 & 0.016 & 0.007 & 0.016 & 0.007 & 0.01 \\
\hline
\end{tabular}


Table 4. Standard of permissible reset.

\begin{tabular}{|l|c|c|}
\hline \multicolumn{1}{|c|}{ Indicator name } & $\begin{array}{c}\text { Unit of } \\
\text { measurement }\end{array}$ & Current discharge requirements \\
\hline Ammonium ion & $\mathrm{mg} / \mathrm{l}$ & 0.50 \\
\hline BOD $_{5}$ & $\mathrm{mgO} / 1$ & 2.05 \\
\hline Suspended solids & $\mathrm{mg} / \mathrm{l}$ & 13.0 \\
\hline Total iron & $\mathrm{mg} / \mathrm{l}$ & 0.11 \\
\hline etroleum products & $\mathrm{mg} / 1$ & 0.08 \\
\hline Nitrate ion & $\mathrm{mg} / \mathrm{l}$ & 40.00 \\
\hline Nitrite ion & $\mathrm{mg} / 1$ & 0.10 \\
\hline Anionic surfactants & $\mathrm{mg} / 1$ & 0.99 \\
\hline Phosphate ion (on $\mathrm{P})$ & $\mathrm{mg} / \mathrm{l}$ & 0.22 \\
\hline COD & $\mathrm{mgO} / 1$ & 30.0 \\
\hline
\end{tabular}

In the current situation, with the «traditional» scheme, the low efficiency of biological treatment processes, namely in the operation of aeration tanks, is revealed, and achieving the requirements for the discharge of pollutants is impossible without the use of special technologies that require the reconstruction of treatment facilities and the re-technology of biological treatment facilities.

The simulation of the operation of biological treatment facilities was carried out using a computer program based on the mathematical models ASM (ASM2d, ASM3), EAWAG, which were first published in 2000-2003 [14, 20, 21]. The developer of the models is a special group for mathematical modeling of the International Water Association [22]. The simulation allows us to calculate biological sewage water treatment facilities that operate according to various technological schemes. Currently, the modeling of cleaning processes using such models is a mandatory attribute of international design requirements.

In the program, the ASM and EAWAG models are supplemented with a hydraulic model, where the aeration tank is presented in the form of several full mixing reactors, to which any amount of liquid can be added or removed from them. The processes of secondary sedimentation tanks are described by the balance equations.

To perform calculations in a computer program, the aeration tanks were conditionally divided into equal sections, taking into account the existing layout of aeration elements, taking into account the presence of primary sedimentation tanks and the joint removal of sediment. In addition, to refine the initial data for calibration of the models, additional studies of the qualitative composition of incoming sewage water were conducted during a 24-hour period of two separately selected days (Table 5). 
Table 5. Qualitative composition for model calibration.

\begin{tabular}{|c|c|c|c|c|c|c|c|c|c|}
\hline Indicator name & $\begin{array}{c}\text { Unit of } \\
\text { measure- } \\
\text { ment }\end{array}$ & $00-00$ & $3-00$ & $6-00$ & $9-00$ & $12-00$ & $15-00$ & $18-00$ & $21-00$ \\
\hline \multicolumn{10}{|c|}{ Sampling 24.08.2017 } \\
\hline COD shaken up & $\mathrm{mgO}_{2} / \mathrm{l}$ & 560 & 380 & 320 & 720 & 980 & 700 & 340 & 300 \\
\hline COD filtered & $\mathrm{mgO}_{2} / 1$ & 280 & 210 & 240 & 340 & 300 & 340 & 210 & 200 \\
\hline $\mathrm{BOD}_{5}$ shaken up & $\mathrm{mgO}_{2} / 1$ & 216 & 297 & 224 & 270 & 199 & 300 & 280 & 333 \\
\hline $\mathrm{BOD}_{5}$ filtered & $\mathrm{mgO}_{2} / \mathrm{l}$ & 100 & 180 & 116 & 147 & 143 & 187 & 155 & 108 \\
\hline Suspended solids & $\mathrm{mg} / \mathrm{l}$ & 547 & 207 & 148 & 534 & 467 & 222 & 249 & 295 \\
\hline Ammonium ion & $\mathrm{mg} / \mathrm{l}$ & 40,5 & 41.7 & 47.6 & 74.0 & 58.5 & 46.4 & 45.7 & 40.3 \\
\hline Total phosphorus & $\mathrm{mg} / \mathrm{l}$ & 2.43 & 2.25 & 2.28 & 4.76 & 3.40 & 3.07 & 3.00 & 2.39 \\
\hline Phosphate ion & $\mathrm{mg} / \mathrm{l}$ & 7.36 & 6.82 & 6.90 & 14.4 & 10.3 & 9.3 & 9.1 & 7.24 \\
\hline \multicolumn{10}{|c|}{ Sampling 28.08.2017 } \\
\hline COD shaken up & $\mathrm{mgO}_{2} / \mathrm{l}$ & 620 & 480 & 340 & 980 & 680 & 760 & 760 & 980 \\
\hline COD filtered & $\mathrm{mgO}_{2} / \mathrm{l}$ & 320 & 300 & 210 & 210 & 370 & 200 & 260 & 360 \\
\hline $\mathrm{BOD}_{5}$ shaken up & $\mathrm{mgO}_{2} / \mathrm{l}$ & 348 & 229 & 180 & 345 & 341 & 364 & 400 & 385 \\
\hline $\mathrm{BOD}_{5}$ filtered & $\mathrm{mgO}_{2} / \mathrm{l}$ & 201 & 94 & 81 & 156 & 180 & 148 & 171 & 170 \\
\hline Suspended solids & $\mathrm{mg} / \mathrm{l}$ & 358 & 232 & 183 & 494 & 214 & 505 & 469 & 564 \\
\hline Ammonium ion & $\mathrm{mg} / \mathrm{l}$ & 46.1 & 50.8 & 51.9 & 70.7 & 53.1 & 55.6 & 46.2 & 55 \\
\hline Total phosphorus & $\mathrm{mg} / \mathrm{l}$ & 2.60 & 2.97 & 2.60 & 3.68 & 3.38 & 2.04 & 2.60 & 3.20 \\
\hline Phosphate ion & $\mathrm{mg} / \mathrm{l}$ & 8.80 & 9.00 & 7.90 & 11.2 & 10.2 & 6.20 & 7.90 & 9.70 \\
\hline
\end{tabular}

All organic substances containing biogenic elements were represented as biologically degradable and biologically non-degradable [23]. Each substance from these groups can be attributed to compounds that are in dissolved and undissolved form (colloidal and suspended particles). In addition, sewage water contains mineral forms of biogenic elements.

For calculations based on a computer model, carbon-containing substances are decomposed according to the above characteristics in units of COD (Figure 1) [14, 22]. All substances in the sewage liquid are divided into dissolved (indicated by the letter $\mathrm{S}$ with indexes) and undissolved (indicated by the letter X with indexes) substances [14]. In turn, each of these types of substances, including those containing nitrogen and phosphorus, is divided into biologically non - degradable (hereinafter referred to as the lower index Iinert) and biologically degradable (other indices). As a generalized characteristic of carboncontaining substances, COD is used, which is possessed by biologically degradable and biologically non-degradable substances.

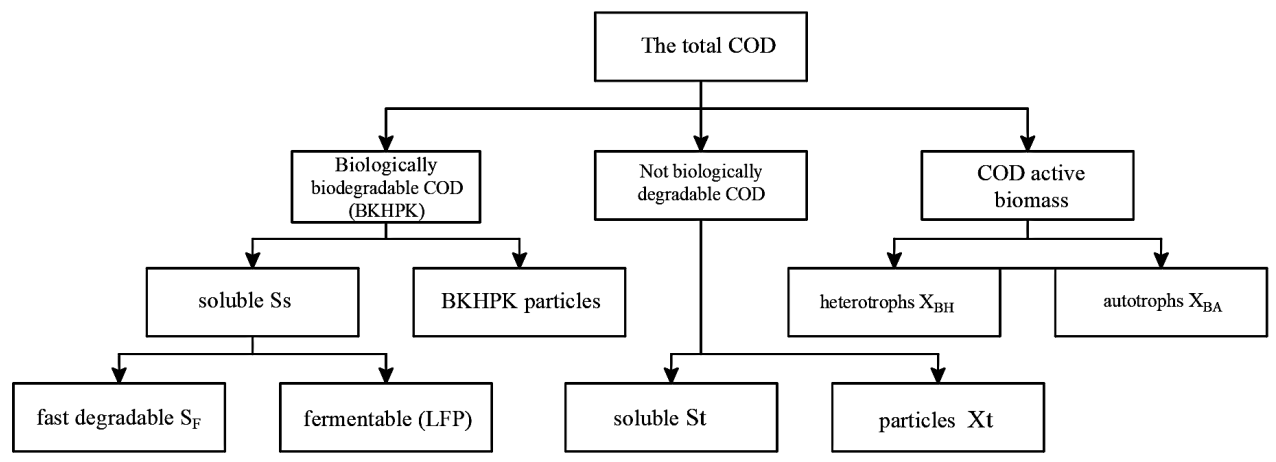

Fig 1. Division of carbon-containing components. 
It is obvious that biologically decomposable substances, dissolved and undissolved and evaluated by the indicators of BOD and COD, can not represent a single compound [24]. An accurate description of the kinetics of their use in the processes of assimilation and dissimilation of microorganisms is currently impossible. However, the division into two groups - fast decomposable and slow decomposable, allowed us to create a satisfactory mathematical description of this process.

The values of $\mathrm{COD}$ and $\mathrm{BOD}_{5}$ samples obtained in the laboratory were used as initial data for the distribution of fractional indicators. Subsequently, the fractionation data was used as a source for creating a mathematical model and obtaining cleaning results similar to the operational data. The results of the fractional distribution of the main organic indicators are shown in Table 6 and in Figure 2 and Figure 3.

Table 6. Fractionation of $\mathrm{COD}$ and $\mathrm{BOD}_{5}$ for sewage treatment plants.

\begin{tabular}{|c|c|c|c|c|c|}
\hline Indicator name & $\begin{array}{c}\text { Dissolved } \\
\text { inert gases } \\
(\mathrm{Si})\end{array}$ & $\begin{array}{c}\text { Colloidal } \\
\text { Substrate } \\
(\mathrm{Scol})\end{array}$ & $\begin{array}{c}\text { Oxidizable } \\
(\mathrm{Ss})\end{array}$ & $\begin{array}{c}\text { Suspended } \\
\text { inert (Xi) }\end{array}$ & $\begin{array}{c}\text { Slowly } \\
\text { oxidized } \\
(\mathrm{Xs})\end{array}$ \\
\hline $\mathrm{COD}_{\mathrm{mgO}} / 1$ & 31.9 & 59.4 & 127.8 & 83 & 336.6 \\
\hline $\begin{array}{c}\mathrm{BOD}_{5}, \\
\mathrm{mgO}_{2} / 1\end{array}$ & 0 & 59.4 & 127.8 & 0 & 142.3 \\
\hline
\end{tabular}

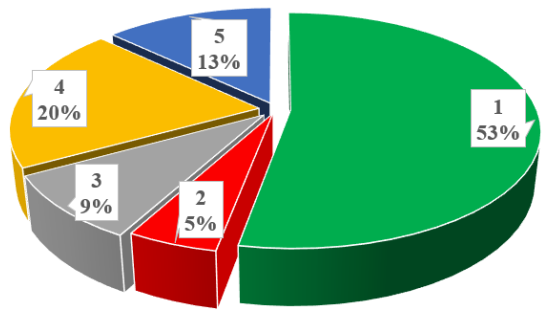

Fig 2. Fractional distribution of COD: 1-slowly oxidizable (Xs), 2-inert (Si), 3 - colloidal substrate (Scol), 4-oxidizable (Ss), 5-inert (Xi)

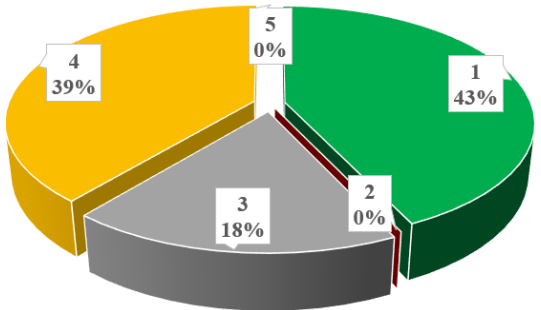

Fig 3. Fractional distribution of $\mathrm{BOD}_{5}$ : 1slowly oxidizable (Xs), 2-inert (Si), 3 colloidal substrate (Scol), 4-oxidizable (Ss), 5inert (Xi)

It should be noted that the presented values of the fractional distribution of COD show that the latter in the incoming sewage water is largely represented by suspended slowly oxidized substances, which causes a low efficiency of sewage water treatment in aeration tanks at present. In the case of BOD, slowly oxidized substances also predominate.

After mathematical processing, the results obtained were comparable to the operational values. Accordingly, the separation into fractions of organic compounds represented by COD is made accurately, and the obtained values will be used to adjust the mathematical model.

\section{Results and discussion}

The choice of a scheme for the reconstruction of biological treatment facilities is the main stage that determines the concept of the development of sewage treatment facilities. The technological efficiency of biological treatment facilities at the modeling stage is determined depending on the loads on the facilities for organic and biogenic elements.

The first stage for designing the technological scheme and predicting the quality of sewage water treatment is the modeling of the initial quality of treatment (calibration of the 
model) [14, 25-27]. The model was adapted to the actual composition and consumption of sewage water, as well as the actual air consumption for aeration.

The calculations showed that the calculated and actual values have a sufficiently high degree of convergence, and are the basis for further research by mathematical modeling of biological purification processes using the program. The initial data for the simulation is taken from Table 1, with the refinement of the additional fractional coefficients noted in the additional analyses in Table 3.

The following parameters were studied: the concentration of ammonium nitrogen, nitrite nitrogen, nitrates, phosphate phosphorus, and sludge growth.

The real volume mass transfer coefficient of oxygen $\left(\mathrm{K}_{\mathrm{La}}\right)$ is taken into account according to the model as follows [21, 27]:

$$
\begin{gathered}
\frac{d \mathrm{SO}_{2}}{d t}=\frac{C R_{\mathrm{SO}_{2}}-\mathrm{SO}_{2}}{C R T}+K_{L} a \cdot\left(\mathrm{C}_{a}-\mathrm{SO}_{2}\right)+V_{\mathrm{So}_{2}} \\
K_{L} a=S O T E \cdot \frac{Q_{\text {air }}}{I_{\text {air }}} \cdot \frac{24 \cdot K_{3} \cdot K_{1} \cdot \rho}{C_{a s t} \cdot \frac{V_{y u}}{I_{\text {air }}}} \cdot 10 \cdot 0,232
\end{gathered}
$$

where SOTE $\left(q_{a i r}, h_{a}\right)$ - is the mass transfer coefficient of oxygen; $K_{3}(a)$ - a-factor, sewage water quality coefficient; $K_{t}$ - temperature coefficient of sewage water; $p$ - air density at normal pressure; $C_{a s t}$ - oxygen solubility at $20^{\circ} \mathrm{C}$ at a depth of $h_{\mathrm{a}} ; V_{u c h}-$ specific volume of air per 1 p. $\mathrm{m}$. of the aerator; 0.232 - mass fraction of oxygen in the air; 10 - conversion factor.

The required number of aerators is determined by the formula [21, 27]:

$$
n=\frac{Q_{\text {air }}}{q_{\text {dif }}}=\frac{1}{q_{\text {dif }}} \times \frac{O U_{h} \cdot C_{\text {st.h }} \cdot 100}{0,232 \cdot 1,2 \cdot S O T E_{h . q d i f} \cdot k_{i} \cdot \alpha \cdot\left(\beta \cdot C_{s t . h}-C_{f}\right)}
$$

where $Q_{\text {air }}$ - is the calculated air flow rate under normal conditions, $\mathrm{m}^{3} / \mathrm{h} ; q_{\text {dif }}-$ nominal value of specific air flow, $\mathrm{m}^{3} / \mathrm{m}$ (pcs.) $*$ h, Table measurement; $C_{s t, h}-$ the average value of the saturation concentration of dissolved oxygen at the depth of the aeration tank $\mathrm{h}(\mathrm{m})$, $\mathrm{mg} / \mathrm{dm}^{3}$, at a temperature of $20^{\circ} \mathrm{C} ; S O T E_{\text {hqdif }}$ - value of the standard efficiency of air oxygen use during aeration; $a=0,8$ - water quality coefficient; $B=1$ - the coefficient of influence of the sewage liquid on the solubility of oxygen.

The throughput capacity of the «aeration tank-secondary sedimentation tank» system according to the calculation of the ATV standard with the actual quality composition of

\begin{tabular}{|c|c|c|}
\hline \multicolumn{3}{|l|}{ Source data } \\
\hline \multicolumn{2}{|l|}{ Name } & Data \\
\hline \multicolumn{2}{|c|}{ Sewage water consumption: daily } & $40000 \mathrm{~m}^{3} /$ day \\
\hline \multicolumn{2}{|c|}{ maximum hourly } & $2515 \mathrm{~m}^{3} / \mathrm{h}$ \\
\hline \multicolumn{2}{|l|}{ Kgen max } & 1.509 SNiP \\
\hline \multicolumn{2}{|c|}{ Movement of water in secondary sedimentation tanks } & horizontal \\
\hline \multicolumn{2}{|c|}{ Activated sludge consumption (in fractions) } & 0.57 \\
\hline \multicolumn{2}{|l|}{ Sludge index } & $100 \mathrm{ml} / \mathrm{g}$ \\
\hline \multirow{2}{*}{\multicolumn{3}{|c|}{$\begin{array}{l}\text { Average winter water temperature } \\
\text { Quality of drains with primary sedimentation }\end{array}$}} \\
\hline & & \\
\hline \multicolumn{2}{|l|}{ Sewage water parameters } & Required purified \\
\hline $\mathrm{COD}$ & 584 & $30 \mathrm{mg} / \mathrm{l}$ \\
\hline $\mathrm{BOD}_{5}$ & 345 & $2 \mathrm{mg} / \mathrm{l}$ \\
\hline
\end{tabular}
incoming sewage water is given in Table 7.

Table 7. Simulation results. 


\begin{tabular}{|c|c|c|}
\hline Suspended solids & 338.6 & $13 \mathrm{mg} / \mathrm{l}$ \\
\hline Ammonium nitrogen & 59.5 & $0.39 \mathrm{mg} / \mathrm{l}$ \\
\hline Nitrogen of nitrates + nitrites & 0.3 & $9.03 \mathrm{mg} / \mathrm{l}$ \\
\hline Phosphorous of phosphates & 14.1 & $0.072 \mathrm{mg} / \mathrm{l}$ \\
\hline \multicolumn{3}{|l|}{ Characteristics of structures } \\
\hline \multicolumn{2}{|c|}{ Surface area of secondary sedimentation tanks } & $1985 \mathrm{~m}^{2}$ \\
\hline \multicolumn{2}{|c|}{ Depth of secondary sedimentation tanks } & $3.7 \mathrm{~m}$ \\
\hline \multicolumn{2}{|c|}{ Secondary sedimentation tank capacity } & $7360 \mathrm{~m}^{3}$ \\
\hline \multicolumn{3}{|l|}{ Calculation of the work } \\
\hline \multicolumn{2}{|l|}{ load $\mathrm{BOD}_{5}$} & $13800 \mathrm{~kg} / \mathrm{day}$ \\
\hline \multicolumn{2}{|l|}{ Stock ratio } & 1.45 \\
\hline \multicolumn{2}{|c|}{ Estimated aerobic age of sludge } & 6.62 days \\
\hline \multicolumn{2}{|c|}{ Updated age of slit } & 13.14 days \\
\hline \multicolumn{3}{|c|}{ Calculation of secondary sedimentation tanks: } \\
\hline \multicolumn{2}{|c|}{ Duration of settling of the sludge mixture } & $2.926 \mathrm{~h}$ \\
\hline \multicolumn{2}{|c|}{ Bottom sludge concentration in secondary sedimentation tanks } & $14.3 \mathrm{~g} / 1$ \\
\hline \multicolumn{2}{|c|}{ Return sludge concentration } & $8.58 \mathrm{~g} / 1$ \\
\hline \multicolumn{2}{|c|}{ The dose of sludge in the aeration tank } & $3.065 \mathrm{~g} / \mathrm{l}$ \\
\hline \multicolumn{2}{|c|}{ Removal of sewage water from secondary sedimentation tanks } & $18.66 \mathrm{mg} / \mathrm{l}$ \\
\hline \multicolumn{2}{|c|}{ Load on the volume of sludge in secondary sedimentation tanks } & $388.41 / \mathrm{m}^{2} * \mathrm{~h}$ \\
\hline \multicolumn{2}{|c|}{ Maximum surface load secondary sedimentation tanks } & $1.267 \mathrm{~m}^{3} / \mathrm{m}^{2 *} \mathrm{~h}$ \\
\hline \multicolumn{2}{|c|}{ Organic nitrogen at the inlet } & $18.55 \mathrm{mg} / \mathrm{l}$ \\
\hline \multicolumn{2}{|l|}{ Total incoming nitrogen } & $78.4 \mathrm{mg} / \mathrm{l}$ \\
\hline \multicolumn{2}{|l|}{ Organic nitrogen output } & $2.0 \mathrm{mg} / \mathrm{l}$ \\
\hline \multicolumn{2}{|c|}{ Nitrogen included in the biomass } & $15.53 \mathrm{mg} / \mathrm{l}$ \\
\hline \multicolumn{2}{|l|}{ Nitrogen removed } & $51.4 \mathrm{mg} / \mathrm{l}$ \\
\hline \multicolumn{2}{|c|}{ Percentage of denitrification zones } & 0.497 \\
\hline Phosphorus concentration in & ated waters & $8.19 \mathrm{mg} / \mathrm{l}$ \\
\hline Phosphorus accumulated in 1 & mass & $3.45 \mathrm{mg} / \mathrm{l}$ \\
\hline Phosphorus required for bior & ss growth & $4.31 \mathrm{mg} / \mathrm{l}$ \\
\hline Total phosphorus of incomin & ewage water & $15.96 \mathrm{mg} / 1$ \\
\hline Daily increase in sludge whe & rganic matter is removed & $13139 \mathrm{~kg} /$ day \\
\hline Daily increase in sludge whe & hosphorus is removed & $518 \mathrm{~kg} /$ day \\
\hline Sludge growth & & $13657 \mathrm{~kg} /$ day \\
\hline Weight of suspended substar & $\mathrm{s}$ in aeration tanks & $179500 \mathrm{~kg}$ \\
\hline Required capacity of aeration & nks & $58565 \mathrm{~m}^{3}$ \\
\hline Internal recycling (in fractio & & 5.03 \\
\hline Consumption of activated sly & by calculation (in fractions) & 0.556 \\
\hline Volume load by BOD $_{5}$ & & 0.236 \\
\hline Load on sludge by $\mathrm{BOD}_{5}$ & & 0.077 \\
\hline Average aeration period & & $35.14 \mathrm{~h}$ \\
\hline Minimum aeration period & & $23.28 \mathrm{~h}$ \\
\hline Oxygen consumption for org & ic oxidation & $649 \mathrm{~kg} / \mathrm{h}$ \\
\hline Oxygen consumption for nit & cation & $431.0 \mathrm{~kg} / \mathrm{h}$ \\
\hline Oxygen release during denit & cation & $248.5 \mathrm{~kg} / \mathrm{h}$ \\
\hline Total oxygen consumption t & ng into account unevenness & $1095 \mathrm{~kg} / \mathrm{h}$ \\
\hline Estimated sewage water con & nption: daily & $9697 \mathrm{~m}^{3} /$ day \\
\hline Maximum hourly & & $1214 \mathrm{~m}^{3} / \mathrm{h}$ \\
\hline Kgen max & & $1.458 \mathrm{SNiP}$ \\
\hline
\end{tabular}

The result of the simulation protocol according to the ATV standard (Table 7), showed that the throughput capacity of treatment facilities when operating under the existing sewage 
water treatment scheme was $\mathrm{Q}=9,697 \mathrm{~m}^{3} /$ day. The limiting factor is the capacity of the aeration tanks and the significant introduction of pollutants in the inefficient primary sedimentation of sewage water. The limitation in the throughput capacity of biological sewage water treatment is due to high concentrations of organic substances and nitrogen compounds, as well as limited routine recycling for their disposal.

The result of the simulation protocol according to the ATV standard of the "aeration tank-secondary sedimentation tank» system with a qualitative composition of incoming sewage water after primary sedimentation tanks without co-deposition of raw sludge and excess sludge, showed that the throughput capacity of treatment facilities was $Q=19,997$ $\mathrm{m}^{3} /$ day, the limiting factor is also the capacity of the aeration tanks.

The variants of reconstruction of aeration tanks, arrangement and modification of recycles for deeper biological treatment according to the following schemes are considered:

- option 1 - scheme without supplying excess activated sludge into the primary sedimentation tank;

- option 2 - scheme with the supply of excess activated sludge to the primary sedimentation tank and the specified concentration of suspended substances at the entrance to the aeration tank (automated removal of sediment from the sedimentation tank);

- option 3 - scheme involving the use of existing primary sedimentation tanks, their conversion to anoxic and anaerobic zones with the installation of mechanical agitators.

Table 8 presents the data of the cleaning scheme for option 1.

Table 8a. Scheme of biological sewage water treatment in aeration tanks-Option 1.

\begin{tabular}{|c|c|c|c|c|c|}
\hline Aeration tank section $\mathrm{N}$ & & 1 & 2 & 3 & 4 \\
\hline Section length, $\mathrm{m}$ & - & 30 & 30 & 30 & 30 \\
\hline Sewage water discharge, $\mathrm{m}^{3} /$ day & - & 8163 & - & - & - \\
\hline $\begin{array}{l}\text { Recirculation flow inlet from the } \\
\text { secondary sedimentation tank, } \\
\mathrm{m}^{3} / \text { day }\end{array}$ & - & 4898 & - & - & - \\
\hline $\begin{array}{l}\text { Recirculation flow inlet: } \\
\text { from the end of } 4 \text { section, } \mathrm{m}^{3} / \text { day } \\
\text { from the end of } 8 \text { sections, } \mathrm{m}^{3} / \text { day }\end{array}$ & - & $\begin{array}{c}200000 \\
8163\end{array}$ & - & - & - \\
\hline Heterotrophic biomass, mg / $1 \mathrm{XH}$ & 0 & 824 & 825 & 824.8 & 825 \\
\hline Autotrophic biomass, mg / 1 XA & 0 & 145.8 & 145.7 & 145.9 & 145.8 \\
\hline $\begin{array}{l}\text { COD of spare substances, } \mathrm{mg} / \mathrm{l} \\
\text { XSTO }\end{array}$ & 0 & 10.4 & 10.5 & 10.21 & 9.74 \\
\hline Inert part of $\mathrm{BB}, \mathrm{mg} / \mathrm{l} \mathrm{XI}$ & 28.5 & 2850 & 2850 & 2850 & 2850 \\
\hline Oxidizable part of $\mathrm{BB}, \mathrm{mg} / \mathrm{l}$ of $\mathrm{XS}$ & 85.6 & 20.74 & 20.23 & 19.73 & 19.25 \\
\hline $\begin{array}{l}\text { Phosphates-accumulating organisms, } \\
\text { mg/l HRAO }\end{array}$ & 0 & 0.0057 & 0.0057 & 0.0057 & 0.0057 \\
\hline $\begin{array}{l}\text { Phosphorus-accumulating organic } \\
\text { products, mg / I XPHA }\end{array}$ & 0 & 0.00009 & 0.0001 & 0.00009 & 0.00009 \\
\hline Polyphosphates, mg / 1 XRP & 0 & 0.00072 & 0.00072 & 0.00072 & 0.00072 \\
\hline $\begin{array}{l}\text { Biodegradable part of dissolved } \\
\text { organic matter, mg BOD / I SS }\end{array}$ & 111.5 & 1.619 & 0.674 & 0.3216 & 0,2458 \\
\hline Inert organic matter, mg / 1 SI & 33.7 & 33.7 & 33.7 & 33.7 & 33.7 \\
\hline Ammonium nitrogen, $\mathrm{mg} / 1 \mathrm{SNH}$ & 57.1 & 14.03 & 14.05 & 13.17 & 13.12 \\
\hline $\begin{array}{l}\text { Nitrogen of nitrates }+ \text { nitrites, } \mathrm{mg} / \mathrm{l} \\
\text { SNO }\end{array}$ & 78 & 8.55 & 8.2 & 8.97 & 8.78 \\
\hline Molecular nitrogen, mg/l & 0 & 37.98 & 38.3 & 38.44 & 38.67 \\
\hline Phosphorous of phosphates, mg / 1 & 5.8 & 5.717 & 5.71 & 5.71 & 5.709 \\
\hline
\end{tabular}




\begin{tabular}{|l|c|c|c|c|c|}
\hline $\mathrm{PO}_{4}$ & & & & & \\
\hline Oxygen, mg / I SO & 0 & 0.00562 & 0.00019 & 261 & 0.00952 \\
\hline Alkalinity, mmol / 1 SHCO & 6 & 2323 & 2348 & 2.23 & 2.24 \\
\hline Suspended solids, $\mathrm{mg} / 1$ & - & 3017 & 3016.9 & 3016.7 & 3016.4 \\
\hline Oxygen consumption, $\mathrm{kgO}_{2} / \mathrm{h}$ & - & 0 & 0 & 42.77 & 0 \\
\hline Total oxygen consumption & \multicolumn{2}{|c|}{$109.5 \mathrm{kgO} / \mathrm{h}$} & - & - & - \\
\hline Total nitrogen & \multicolumn{2}{|c|}{$19.07 \mathrm{mg} / 1$} & - & - & - \\
\hline Total phosphorus & \multicolumn{2}{|c|}{$5.82 \mathrm{mg} / 1$} & - & - & - \\
\hline Number of rows of aerators & 0 & 0 & 4 & 0 & 0 \\
\hline Total length of aerators, $\mathrm{m}$ & 0 & 0 & 112 & 0 & 0 \\
\hline Air consumption for oxidation, $\mathrm{m}^{3} / \mathrm{h}$ & 0 & 0 & 1120 & 0 & 0 \\
\hline for mixing ATV, $\mathrm{m}^{3} / \mathrm{h}$ & 0 & 0 & 394 & 0 & 0 \\
\hline Specific air consumption, $\mathrm{m}^{3} / \mathrm{h}^{*} \mathrm{~m}$ & 0 & 0 & 10.00 & 0 & 0 \\
\hline SOTE, \% & 0 & 0 & 16.6 & 0 & 0 \\
\hline
\end{tabular}

Table 8b. Scheme of biological sewage water treatment in aeration tanks-Option 1.

\begin{tabular}{|c|c|c|c|c|}
\hline Aeration tank section $\mathrm{N}$ & 5 & б & 7 & 8 \\
\hline Section length, $\mathrm{m}$ & 30 & 30 & 30 & 30 \\
\hline Heterotrophic biomass, mg/l XH & 827 & 825 & 822.9 & 818 \\
\hline Autotrophic biomass, mg / 1 XA & 145.4 & 145.9 & 146.4 & 146.4 \\
\hline COD of spare substances, mg/l XSTO & 6.48 & 4.44 & 3.18 & 2466 \\
\hline Inert part of $\mathrm{BB}, \mathrm{mg} / \mathrm{l} \mathrm{XI}$ & 2851 & 2852 & 2853 & 2854 \\
\hline Oxidizable part of $\mathrm{BB}, \mathrm{mg} / \mathrm{l} \mathrm{XS}$ & 15.2 & 12 & 9.48 & 7.48 \\
\hline $\begin{array}{l}\text { Phosphates-accumulating organisms, } \mathrm{mg} / \mathrm{l} \\
\text { XPAO }\end{array}$ & 0.0057 & 0 & 0.00568 & 0.00566 \\
\hline $\begin{array}{l}\text { Products of phosphorus-accumulating organic } \\
\text { matter, mg/l XPHA }\end{array}$ & 0.00008 & 0.00006 & 0.00005 & 0.00004 \\
\hline Polyphosphates, mg / 1 XPP & 0.00072 & 0.00073 & 0.00073 & 0.00074 \\
\hline $\begin{array}{l}\text { Biodegradable part of dissolved organic } \\
\text { matter, mg COD/1 SS }\end{array}$ & 0.1755 & 0.1208 & 0.0928 & 0.0656 \\
\hline Inert organic matter, mg / $1 \mathrm{SI}$ & 33.7 & 33.7 & 33.7 & 33.7 \\
\hline Ammonium nitrogen, mg/l SNH & 13.14 & 8.38 & 3765 & 0.2996 \\
\hline Nitrogen of nitrates + nitrites, $\mathrm{mg} / \mathrm{l} \mathrm{SNO}$ & 6.81 & 10.67 & 14.67 & 18.43 \\
\hline Molecular nitrogen, mg/l & 40.64 & 41.66 & 42.44 & 42.5 \\
\hline Phosphorous of phosphates, mg/l SPO4 & 5.707 & 5.72 & 5.75 & 5.82 \\
\hline Oxygen, mg / $1 \mathrm{SO}$ & 0.00004 & 0.1250 & 0.1645 & 2.84 \\
\hline Alkalinity, mmol/1 SHCO & 2383 & 1767 & 1.15 & 0.6310 \\
\hline Suspended solids, mg / 1 & 3012.8 & 3009.3 & 3305.6 & 3000.0 \\
\hline Oxygen consumption, $\mathrm{kgO}_{2} / \mathrm{h}$ & 0 & 21.69 & 21.6 & 23.44 \\
\hline Number of rows of aerators & 2 & 2 & 3 & 0 \\
\hline Total length of aerators, $\mathrm{m}$ & 56 & 56 & 84 & 0 \\
\hline Air consumption for oxidation, $\mathrm{m}^{3} / \mathrm{h}$ & 560.0 & 560.0 & 840.0 & 0 \\
\hline for mixing $\mathrm{ATV}, \mathrm{m}^{3} / \mathrm{h}$ & 394 & 394 & 394 & 0 \\
\hline Specific air consumption, $\mathrm{m}^{3} / \mathrm{h}^{*} \mathrm{~m}$ & 10.00 & 10.00 & 10.00 & 0 \\
\hline SOTE, $\%$ & 16.6 & 16.6 & 16.6 & 0 \\
\hline
\end{tabular}

Due to the lack of organic pollutants at very high concentrations of ammonium nitrogen compounds, it is possible to reduce the nitrogen of nitrates to only $18-19 \mathrm{mg} / \mathrm{l}$. Thus, the 
imbalance of organic and nitrogen compounds noted in Table 2 ultimately affects the efficiency of biological purification, with low denitrification.

Table 9 presents the data of the purification scheme with effective denitrification according to option 2 . The scheme of biological sewage water treatment according to option 2 is shown in Figure 4.

Table 9a. Scheme of biological treatment in aeration tanks-Option 2.

\begin{tabular}{|c|c|c|c|c|c|}
\hline Aeration tank section $\mathrm{N}$ & - & 1 & 2 & 3 & 4 \\
\hline Plot length, $\mathrm{m}$ & - & 30 & 30 & 30 & 30 \\
\hline Sewage water discharge, $\mathrm{m}^{3} /$ day & - & 8966 & - & - & - \\
\hline $\begin{array}{l}\text { Recirculation flow inlet from the } \\
\text { secondary sedimentation tank, } \mathrm{m}^{3} / \text { day }\end{array}$ & - & 7173 & - & - & - \\
\hline $\begin{array}{l}\text { Recirculation flow inlet: } \\
\text { from the end of } 4 \text { sections, } \mathrm{m}^{3} / \text { day } \\
\text { from the end of section } 8, \mathrm{~m}^{3} / \text { day }\end{array}$ & - & $\begin{array}{c}300000 \\
8966\end{array}$ & - & - & - \\
\hline Heterotrophic biomass, mg/l XH & 0 & 1710 & 1711 & 1712 & 1712 \\
\hline Autotrophic biomass, mg / $1 \mathrm{XA}$ & 0 & 123.4 & 123.4 & 123.5 & 123.5 \\
\hline COD of spare substances, $\mathrm{mg} / \mathrm{l} \mathrm{XSTO}$ & 0 & 34 & 34.5 & 34.19 & 33.60 \\
\hline Inert part of $\mathrm{BB}, \mathrm{mg} / \mathrm{l} \mathrm{XI}$ & 55.48 & 1725 & 1725 & 1725 & 1725 \\
\hline Oxidizable part of $\mathrm{BB}, \mathrm{mg} / \mathrm{l} \mathrm{XS}$ & 312.7 & 80.7 & 79.3 & 78.00 & 76.7 \\
\hline $\begin{array}{l}\text { Phosphates-accumulating organisms, } \\
\text { mg/l XPAO }\end{array}$ & 0 & 8.460 & 8.46 & 8.46 & 8.47 \\
\hline $\begin{array}{l}\text { Products of phosphorus-accumulating } \\
\text { organic matter, mg/1 XPHA }\end{array}$ & 0 & 0.5628 & $0 . .5670$ & 0.5598 & 0.5557 \\
\hline Polyphosphates, mg / 1 XPP & 0 & 1.304 & 1303 & 1305 & 1306 \\
\hline $\begin{array}{l}\text { Biodegradable part of dissolved organic } \\
\text { matter, mg COD/1 SS }\end{array}$ & 180.2 & 2.297 & 1378 & 0.5566 & 488 \\
\hline Inert organic matter, mg / 1 SI & 35.6 & 35.6 & 35.6 & 35.6 & 35.6 \\
\hline Ammonium nitrogen, $\mathrm{mg} / \mathrm{l} \mathrm{SNH}$ & 59.5 & 8.96 & 8.99 & 8.03 & 7868 \\
\hline Nitrogen of nitrates + nitrites, $\mathrm{mg} / \mathrm{l} \mathrm{SNO}$ & 0.32 & 1.004 & 579 & 1.48 & 1336 \\
\hline Molecular nitrogen, $\mathrm{mg} / \mathrm{l}$ & 0 & 55.38 & 55.8 & 55.87 & 56.16 \\
\hline Phosphorous of phosphates, mg/l $\mathrm{SPO}_{4}$ & 14.1 & 13.79 & 13.79 & 13.78 & 13.78 \\
\hline Oxygen, $\mathrm{mg} / \mathrm{l} \mathrm{SO}$ & 0 & 0.00953 & 0.00038 & 1.088 & 0.05886 \\
\hline Alkalinity, mmol/1 SHCO & 6 & 2.357 & 2.390 & 2.257 & 2.256 \\
\hline Suspended solids, mg / 1 & - & 3036.9 & 3036.7 & 3036.3 & 3035.7 \\
\hline Oxygen consumption, $\mathrm{kgO}_{2} / \mathrm{h}$ & - & 0.00001 & 0 & 91.6 & 0.00001 \\
\hline Total oxygen consumption & \multicolumn{2}{|c|}{$185 \mathrm{kgO}_{2} / \mathrm{h}$} & - & - & - \\
\hline Total Nitrogen & \multicolumn{2}{|c|}{$8.33 \mathrm{mg} / 1$} & - & - & - \\
\hline Total phosphorus & \multicolumn{2}{|c|}{$13.86 \mathrm{mg} / \mathrm{l}$} & - & - & - \\
\hline Number of rows of aerators & - & 0 & 0 & 6 & 0 \\
\hline Total length of aerators, $m$ & - & 0 & 0 & 168 & 0 \\
\hline Air consumption for oxidation, $\mathrm{m}^{3} / \mathrm{h}$ & - & 0 & 0 & 2688 & 0 \\
\hline for mixing ATV, $\mathrm{m}^{3} / \mathrm{h}$ & - & 0 & 0 & 394 & 0 \\
\hline SOTE, $\%$ & - & 0 & 0 & 16.2 & 0 \\
\hline
\end{tabular}


Table 9b. Scheme of biological treatment in aeration tanks-Option 2.

\begin{tabular}{|l|c|c|c|c|}
\hline Aeration tank section N & 5 & 6 & 7 & 8 \\
\hline Plot length, m & 30 & 30 & 30 & 30 \\
\hline Heterotrophic biomass, mg/l XH & 1713 & 1718 & 1717 & 1712 \\
\hline Autotrophic biomass, mg / 1 XA & 123.5 & 124.6 & 124.2 & 123.7 \\
\hline COD of spare substances, mg/l XSTO & 38.29 & 28.57 & 20.97 & 16.48 \\
\hline Inert part of BB, mg/l XI & 1725 & 1727 & 1730 & 1733 \\
\hline Oxidizable part of BB, mg/l XS & 62.9 & 51.4 & 42.06 & 34.36 \\
\hline Phosphates-accumulating organisms, mg/l XPAO & 8469 & 8.51 & 8.52 & 8.51 \\
\hline $\begin{array}{l}\text { Products of phosphorus-accumulating organic } \\
\text { matter, mg/l XPHA }\end{array}$ & 835 & 701 & 615 & 0.56 \\
\hline Polyphosphates, mg / XPP & 1208 & 1259 & 1305 & 1346 \\
\hline $\begin{array}{l}\text { Biodegradable part of dissolved organic matter, } \\
\text { mg COD/l SS }\end{array}$ & 4.6 & 0.2954 & 0.1749 & 0.1416 \\
\hline Inert organic matter, mg / l SI & 35.6 & 35.6 & 35.6 & 35.6 \\
\hline Ammonium nitrogen, mg/l SNH & 8.09 & 947 & 0.0799 & 0.13457 \\
\hline Nitrogen of nitrates + nitrites, mg/l SNO & 0.0354 & 6.64 & 7.54 & 7.93 \\
\hline Molecular nitrogen, mg/l & 7.46 & 58.0 & 58.20 & 58.3 \\
\hline Phosphorous of phosphates, mg/l SPO4 & 13.93 & 13.83 & 13.82 & 13.86 \\
\hline Oxygen, mg / l SO & 0.00014 & 1.845 & 2.96 & 4.115 \\
\hline Alkalinity, mmol/l SHCO & 2.354 & 1.379 & 1.254 & 1.222 \\
\hline Suspended solids, mg / l & 3028.8 & 3021.6 & 3010.9 & 2999.9 \\
\hline Oxygen consumption, kgO $/ \mathrm{h}$ & 0 & 52.29 & 22.49 & 18.7 \\
\hline Number of rows of aerators & 0 & 4 & 2 & 2 \\
\hline Total length of aerators, m & 0 & 112 & 56 & 56 \\
\hline Air consumption for oxidation, m ${ }^{3}$ / h & 0 & 1680 & 840 & 840 \\
\hline for mixing ATV, m ${ }^{3}$ h & 0 & 394 & 394 & 394 \\
\hline SOTE, \% & 0 & 16.2 & 16.2 & 16.2 \\
\hline & & & \\
\hline
\end{tabular}

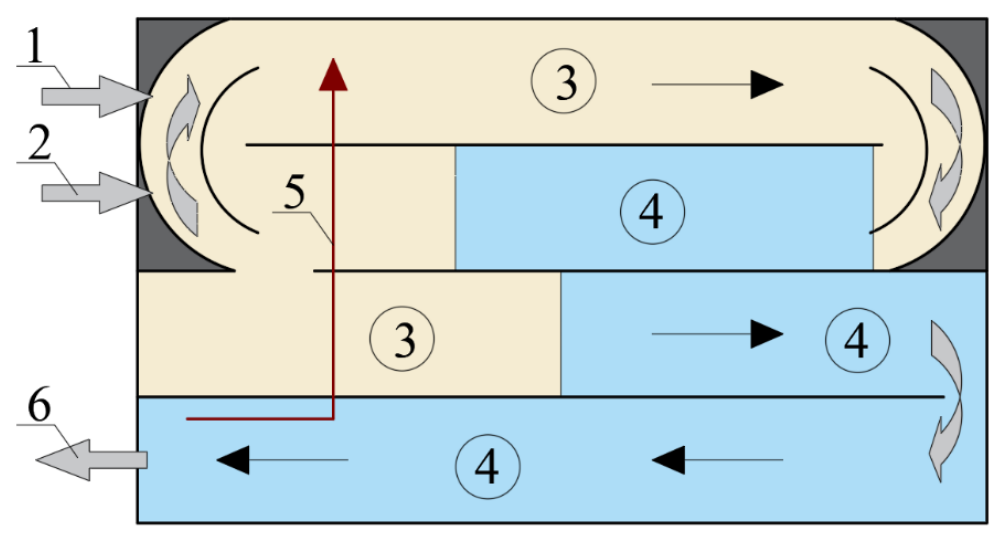

Fig 4. Scheme of biological treatment in aeration tanks according to Option 2: 1-active sludge supply, 2-sewage water supply, 3-mixing zone, 4-aeration zone, 5-sludge mixture recycling, 6-sludge mixture output.

As can be seen from the ATV simulation protocol, in order to reconstruct structures using nitri-denitrification technology, it is necessary to increase the capacity of aeration tanks. However, the circulation of excess activated sludge and its co-deposition with the sediment 
of primary sedimentation tanks increases the load on the biological treatment of phosphates and produces problems in operation with inefficient sediment removal, as well as increases the operating costs of chemical reagent dephosphotation.

In the scheme according to option 3, the formation of raw sludge is excluded, the return activated sludge is fed to the mixing zone (repurposed primary sedimentation tanks), and a «nitrate recycle» is also sent to this zone from the end of the aeration tank (Table 10).

Table 10a. Scheme of biological treatment in aeration tanks-Option 3.

\begin{tabular}{|c|c|c|c|c|c|}
\hline Aeration tank section $\mathrm{N}$ & & 1 & 2 & 3 & 4 \\
\hline Plot length, $\mathrm{m}$ & - & 34 & 34 & 30 & 30 \\
\hline Sewage water discharge, $\mathrm{m}^{3} /$ day & - & 13330 & - & - & - \\
\hline $\begin{array}{l}\text { Recirculation flow inlet from the } \\
\text { secondary sedimentation tank, } \mathrm{m}^{3} / \text { day }\end{array}$ & - & 11000 & - & - & - \\
\hline $\begin{array}{l}\text { Recirculation flow inlet: } \\
\text { from the end of the } 10 \text { section, } \mathrm{m}^{3} / \text { day }\end{array}$ & - & 100000 & - & - & - \\
\hline Heterotrophic biomass, mg/l XH & 0 & 1089 & 1091 & 1092 & 1093 \\
\hline Autotrophic biomass, mg/l XA & 0 & 125 & 124.9 & 124.9 & 124.8 \\
\hline COD of spare substances, mg/l XSTO & 0 & 18.16 & 1.36 & 17.25 & 16.04 \\
\hline Inert part of $\mathrm{BB}, \mathrm{mg} / \mathrm{l} \mathrm{XI}$ & $\begin{array}{c}42.5 \\
7\end{array}$ & 1304 & 1304 & 1304 & 1304 \\
\hline Oxidized part of BB, mg/l XS & $\begin{array}{c}127 . \\
7\end{array}$ & 35.17 & 33.47 & 32.03 & 30.66 \\
\hline $\begin{array}{l}\text { Phosphates-accumulating organisms, } \\
\text { mg/l XPAO }\end{array}$ & 0 & $\begin{array}{c}0.0036 \\
25\end{array}$ & $\begin{array}{c}0.0036 \\
27\end{array}$ & $\begin{array}{c}0.0036 \\
29\end{array}$ & $\begin{array}{c}0.0036 \\
3\end{array}$ \\
\hline $\begin{array}{l}\text { Products of phosphorus-accumulating } \\
\text { organic matter, mg/l XPHA }\end{array}$ & 0 & $\begin{array}{c}0.0000 \\
89\end{array}$ & $\begin{array}{c}0.0000 \\
91\end{array}$ & $\begin{array}{c}0.0000 \\
9\end{array}$ & $\begin{array}{c}0.0000 \\
88\end{array}$ \\
\hline Polyphosphates, mg/l XPP & 0 & $\begin{array}{c}0.0004 \\
81 \\
\end{array}$ & $\begin{array}{c}0.0004 \\
80\end{array}$ & $\begin{array}{c}0.0048 \\
1 \\
\end{array}$ & $\begin{array}{c}0.0004 \\
81\end{array}$ \\
\hline $\begin{array}{l}\text { Biodegradable part of dissolved } \\
\text { organic matter, mg COD/1 SS }\end{array}$ & $\begin{array}{c}166 . \\
4\end{array}$ & 3.709 & 0.854 & 0.394 & 0.3094 \\
\hline Inert organic matter, mg/l SI & 50.3 & 50.3 & 50.3 & 50.3 & 50.3 \\
\hline Ammonium nitrogen, mg/l SNH & 57.1 & 6.59 & 6.628 & 6.609 & 6.59 \\
\hline Nitrogen of nitrates + nitrites, $\mathrm{mg} / \mathrm{l} \mathrm{SNO}$ & 0.1 & 4.968 & 3.94 & 3.287 & 2.707 \\
\hline Molecular nitrogen, $\mathrm{mg} / \mathrm{l}$ & 0 & 49.46 & 50.49 & 51.1 & 51.7 \\
\hline Phosphorous of phosphates, $\mathrm{mg} / \mathrm{l} \mathrm{SPO} 4$ & 3.92 & 3.556 & 3.545 & 3.536 & 3.530 \\
\hline Alkalinity, mmol/l SHCO & 7 & 3.06 & 3.139 & 3.184 & 3.224 \\
\hline $\begin{array}{l}\text { Ash-free part of BB, mg/l, MLVSS } \\
\text { XTSS }\end{array}$ & - & 2108.1 & 2108.1 & 2107.3 & 2106.4 \\
\hline Oxygen consumption, $\mathrm{kg} \mathrm{O}_{2} / \mathrm{h}$ & - & 0 & 0 & 0 & 0 \\
\hline Total oxygen consumption & \multicolumn{2}{|c|}{$204 \mathrm{kgO}_{2} / \mathrm{h}$} & - & - & - \\
\hline Total nitrogen & \multicolumn{2}{|c|}{$22.95 \mathrm{mg} / \mathrm{l}$} & - & - & - \\
\hline Total phosphorus & \multicolumn{2}{|c|}{$6.649 \mathrm{mg} / \mathrm{l}$} & - & - & - \\
\hline Sludge growth & \multicolumn{2}{|c|}{$95.9 \mathrm{mg} / \mathrm{l}$} & - & - & - \\
\hline Number of rows of aerators & - & 0 & 0 & 0 & 0 \\
\hline Total quantity of aerators & - & 0 & 0 & 0 & 0 \\
\hline Air consumption for oxidation, $\mathrm{m}^{3} / \mathrm{h}$ & - & 0 & 0 & 0 & 0 \\
\hline for mixing ATV, $\mathrm{m}^{3} / \mathrm{h}$ & - & 0 & 0 & 0 & 0 \\
\hline Specific air consumption, $\mathrm{m} 3 / \mathrm{h} * \mathrm{~m}$ & - & 0 & 0 & 0 & 0 \\
\hline SOTE, $\%$ & - & 0 & 0 & 0 & 0 \\
\hline
\end{tabular}


Table 10b. Scheme of biological treatment in aeration tanks-Option 3.

\begin{tabular}{|c|c|c|c|c|c|c|}
\hline Aeration tank section $\mathrm{N}$ & 5 & 6 & 7 & 8 & 9 & 10 \\
\hline Plot length, m & 30 & 30 & 30 & 30 & 30 & 34 \\
\hline $\begin{array}{l}\text { Heterotrophic biomass, } \\
\mathrm{mg} / \mathrm{l} \mathrm{XH}\end{array}$ & 1094 & 1094 & 1094 & 1094 & 1094 & 1093 \\
\hline $\begin{array}{l}\text { Autotrophic biomass, mg/l } \\
\text { XA }\end{array}$ & 124.8 & 124.7 & 125.3 & 125.6 & 125.8 & 125.7 \\
\hline $\begin{array}{l}\text { COD of spare substances, } \\
\text { mg/l XSTO }\end{array}$ & 14.96 & 14.03 & 12.88 & 11.8 & 10.86 & 10.01 \\
\hline Inert part of $\mathrm{BB}, \mathrm{mg} / \mathrm{l} \mathrm{XI}$ & 1304 & 1304 & 1305 & 1305 & 13.05 & 1306 \\
\hline $\begin{array}{l}\text { Oxidized part of BB, mg/l } \\
\text { XS }\end{array}$ & 29.34 & 28.08 & 26.87 & 25.7 & 24.60 & 23.40 \\
\hline $\begin{array}{l}\text { Phosphates-accumulating } \\
\text { organisms, mg/1 XPAO }\end{array}$ & $\begin{array}{c}0.0036 \\
34\end{array}$ & $\begin{array}{l}0.0036 \\
36\end{array}$ & $\begin{array}{c}0.003 \\
637\end{array}$ & $\begin{array}{c}0.0036 \\
38\end{array}$ & $\begin{array}{c}0.0036 \\
38\end{array}$ & $\begin{array}{c}0.0036 \\
3\end{array}$ \\
\hline $\begin{array}{l}\text { Products of phosphorus- } \\
\text { accumulating organic } \\
\text { matter, mg/l XPHA }\end{array}$ & $\begin{array}{c}0.0000 \\
87\end{array}$ & $\begin{array}{c}0.0000 \\
86\end{array}$ & $\begin{array}{c}0.000 \\
081\end{array}$ & $\begin{array}{c}0.0000 \\
77\end{array}$ & $\begin{array}{l}0.0000 \\
73\end{array}$ & $\begin{array}{c}0.0000 \\
7\end{array}$ \\
\hline Polyphosphates, mg/1 XPP & $\begin{array}{c}0.0004 \\
82\end{array}$ & $\begin{array}{c}0.0004 \\
83\end{array}$ & $\begin{array}{c}0.000 \\
484\end{array}$ & $\begin{array}{c}0.0004 \\
86\end{array}$ & $\begin{array}{c}0.0004 \\
88\end{array}$ & $\begin{array}{c}0.0004 \\
9\end{array}$ \\
\hline $\begin{array}{l}\text { Biodegradable part of } \\
\text { dissolved organic matter, } \\
\text { mg COD/1 SS }\end{array}$ & 0.2929 & 0.2924 & $\begin{array}{l}0.189 \\
3\end{array}$ & 0.1693 & 0.16 & 0.152 \\
\hline $\begin{array}{l}\text { Inert organic matter, } \mathrm{mg} / \mathrm{l} \\
\text { SI }\end{array}$ & 50.3 & 50.3 & 50.3 & 50.3 & 50.3 & 50.3 \\
\hline $\begin{array}{l}\text { Ammonium nitrogen, mg/l } \\
\text { SNH }\end{array}$ & 6.57 & 6.55 & 3.67 & 1.513 & 0.4330 & 0.1032 \\
\hline $\begin{array}{l}\text { Nitrogen of } \\
\text { nitrates+nitrites, } \mathrm{mg} / \mathrm{l} \mathrm{SNO}\end{array}$ & 2.172 & 1.678 & 45 & 6.62 & 7.7 & 8.06 \\
\hline Molecular nitrogen, mg/l & 52.25 & 52.7 & 52.79 & 52.8 & 52.9 & 52.88 \\
\hline $\begin{array}{l}\text { Phosphorous of } \\
\text { phosphates, } \mathrm{mg} / \mathrm{l} \mathrm{SPO}_{4}\end{array}$ & 3.524 & 3.53 & 3.514 & 3.51 & 3.515 & 3.524 \\
\hline Alkalinity, mmol/1 SHCO & 3.26 & 3.296 & 2.889 & 2.583 & 2.429 & 2.380 \\
\hline $\begin{array}{l}\text { Ash-free part of BB, mg/l, } \\
\text { MLVSS XTSS }\end{array}$ & 2105.5 & 2104.7 & $\begin{array}{c}2103 . \\
8\end{array}$ & 2102.8 & 2101.6 & 2100.0 \\
\hline $\begin{array}{l}\text { Oxygen consumption, } \mathrm{kg} \\
\mathrm{O}_{2} / \mathrm{h}\end{array}$ & 0 & 0 & 87.8 & 58.78 & 37.59 & 19.9 \\
\hline $\begin{array}{l}\text { Number of rows of } \\
\text { aerators }\end{array}$ & 0 & 0 & 5 & 4 & 3 & 2 \\
\hline Total quantity of aerators & 0 & 0 & 215 & 172 & 129 & 98 \\
\hline $\begin{array}{l}\text { Air consumption for } \\
\text { oxidation, } \mathrm{m}^{3} / \mathrm{h}\end{array}$ & 0 & 0 & 3511 & 1978 & 1290 & 529.5 \\
\hline for mixing ATV, $\mathrm{m}^{3} / \mathrm{h}$ & 0 & 0 & 394 & 394 & 394 & 446.8 \\
\hline $\begin{array}{l}\text { Specific air consumption, } \\
\mathrm{m} 3 / \mathrm{h}^{*} \mathrm{~m}\end{array}$ & 0 & 0 & 16.33 & 11.50 & 9.38 & 5.4 \\
\hline SOTE, $\%$ & 0 & 0 & 14.18 & 16.86 & 18.9 & 22.89 \\
\hline
\end{tabular}


As can be seen from the protocol for modeling processes according to option 3reformatting part of the primary sedimentation tanks under the mixing zone, and using the remaining sedimentation tanks for their intended purpose, allows for high-quality cleaning according to organic indicators and the nitrogen group (nitri-denitrification). However, the biological removal of phosphorus is carried out with a low degree of removal. The advantage of this scheme is lower loads for phosphates and, accordingly, lower operating costs for its chemical reagent removal compared to option 2. The scheme of biological treatment for option 3 is shown in Figure 5.

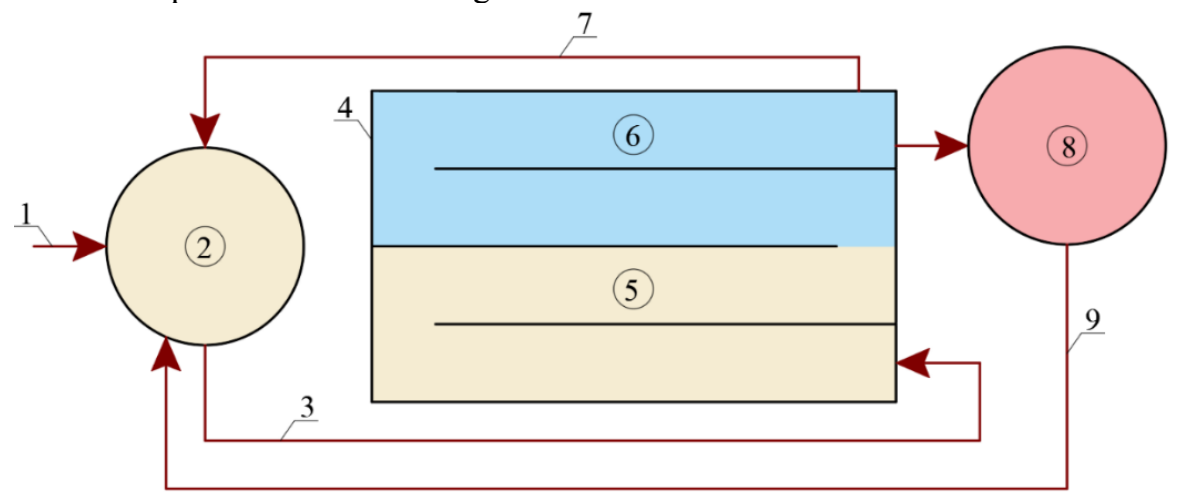

Fig 5. Scheme of biological treatment in aeration tanks according to Option 3: 1-sewage water supply, 2-anaerobic reactor, 3-sludge mixture, 4-aeration tank, 5-mixing zone, 6-aeration zone, 7sludge mixture recycling, 8-secondary sedimentation tank, 9-activated sludge supply.

\section{Conclusions}

Calculations have shown that the existing technological scheme of sewage treatment facilities in Almetyevsk does not allow to achieve the quality of treated sewage water at the level of the MPC for fisheries reservoirs.

The obtained calculation data made it possible to make a variant study of the technological schemes of reconstruction for the design capacity of 40 thousand $\mathrm{m}^{3} /$ day. Modeling of nitri - denitrification and biological phosphorus removal schemes showed that the quality of purification is affected by the ratio of the size of mixing zones (anaerobic and anoxic), the size and location of the sludge mixture recycle. When performing the calculations, the concentrated and dispersed sewage water supply to the aeration tanks was considered.

The most effective option 3 of biological purification in aeration tanks with the use of nitri-denitrification technology was selected, which allows removing not only organic substances, but also nitrogen and partially phosphorus compounds.

The low efficiency of the transport of dissolved oxygen into the sludge mixture contributes to the minimum number of rows of aerators and their wall-mounted arrangement in the aeration tanks. The reconstruction of the existing aeration tanks with the replacement of the aeration system and the introduction of an automatic air supply control system, will ensure the effective removal of organic compounds and ammonium nitrogen, and will also reduce energy consumption.

The achievable quality of sewage water treatment after the reconstruction of sewage treatment plants is presented in Table 11. 
Table 11. Stage-by-stage cleaning efficiency and VAT requirements.

\begin{tabular}{|c|c|c|c|c|c|c|c|}
\hline $\mathrm{N}$ & Name of indicators & $\begin{array}{c}\text { Value in } \\
\text { incoming } \\
\text { water }\end{array}$ & $\begin{array}{c}\text { Effect } \\
\mathrm{BT}, \\
\%\end{array}$ & $\begin{array}{c}\text { After } \\
\mathrm{BT}, \\
\mathrm{mg} / \mathrm{l}\end{array}$ & $\begin{array}{c}\text { Effect } \\
\text { PT, } \\
\%\end{array}$ & $\begin{array}{c}\text { After } \\
\text { PT, } \\
\mathrm{mg} / 1\end{array}$ & $\begin{array}{c}\text { MPC } \\
\mathrm{f}\end{array}$ \\
\hline 1 & 2 & 3 & 4 & 5 & 6 & 7 & 8 \\
\hline 1 & $\mathrm{COD}$ & 387 & 88 & $\begin{array}{c}46.4 \\
4\end{array}$ & 35 & 30.2 & 35 \\
\hline 2 & BOD $_{5}$ & 245.55 & 98.9 & 2.82 & 30 & 202 & 2 \\
\hline 3 & Ammonium ion & 73.425 & 99.4 & 0.44 & 0 & 0.44 & 0.5 \\
\hline 4 & Nitrite anion & 0.007 & 0 & 0.08 & 0 & 0.08 & 0.08 \\
\hline 5 & Nitrate anion & 0.3 & 0 & 40 & 0 & $\begin{array}{c}40.0 \\
0\end{array}$ & 40 \\
\hline 6 & Suspended solids & 310.1 & 96 & $\begin{array}{c}12.4 \\
0\end{array}$ & 60 & 4.96 & 5 \\
\hline 7 & Petroleum products & 1.9 & 95 & 0.10 & 45 & 0.05 & 0.05 \\
\hline 8 & Active surfactants & 2.49 & 93 & 0.17 & 45 & 0.1 & 0.1 \\
\hline 9 & Phosphate ion & 15.6 & 5.0 & $\begin{array}{c}14.7 \\
9\end{array}$ & 95.9 & 0.61 & $\begin{array}{c}0.61 / 0 . \\
2\end{array}$ \\
\hline 10 & Total iron & 2.07 & 94.5 & 0.11 & 10 & 0.1 & 0.1 \\
\hline
\end{tabular}

As can be seen from Table 11, as a result of the reconstruction, the estimated quality of cleaning will meet the standard of permissible discharge in all indicators. The cost of sewage water treatment in accordance with the cost of implementing technological solutions (CAPEX) and operating costs (OPEX) for option 3 is shown in Table 12.

Table 12. Cost indicators.

\begin{tabular}{|c|c|c|c|c|c|}
\hline $\mathrm{N}$ & \multicolumn{3}{|c|}{ Type of deduction } & $\begin{array}{l}\text { Cost name, } \\
\text { RUB/ year }\end{array}$ & $\%$ of costs \\
\hline 1 & \multicolumn{3}{|l|}{2} & 3 & 4 \\
\hline 1 & \multicolumn{3}{|c|}{ Depreciation charges for buildings and structures } & 9600000.0 & 8.16 \\
\hline 2 & \multicolumn{3}{|l|}{ Depreciation on equipment } & 11721278.0 & 9.96 \\
\hline 3 & \multicolumn{3}{|c|}{ Major repairs, current repairs, other expenses } & 14214185.0 & 12.08 \\
\hline \multirow[t]{3}{*}{4} & \multicolumn{3}{|l|}{ Reagent costs (without transportation) } & & \\
\hline & - iron sulfate & 6.3 & $\mathrm{~kg} /$ day & 24658502.0 & 20.95 \\
\hline & - flocculant & 06.5 & $\mathrm{~kg} /$ day & 17492625.0 & 14.86 \\
\hline 5 & Electric power & 750 & $\mathrm{~kW} / \mathrm{h}$ & 28607094.0 & 24.31 \\
\hline 6 & Salary & 21 & $\mathrm{~h}$ & 6804000.0 & 5.78 \\
\hline 7 & Water for process requirements & 965.1 & $\mathrm{~m}^{3} /$ day & 1461864.0 & 1.15 \\
\hline 8 & Removal of sludge to the landfill & 98.6 & $\mathrm{~m}^{3} /$ day & 2159248.0 & 1.83 \\
\hline \multirow[t]{3}{*}{9} & Placement of sludge at the landfill & 98.6 & $\mathrm{~m}^{3} /$ day & 1079624.0 & 0.92 \\
\hline & \multicolumn{3}{|l|}{ Total } & 117689114.0 & 100.0 \\
\hline & \multicolumn{3}{|c|}{ Cost of cleaning $1 \mathrm{~m}^{3}$} & 8.06 & \\
\hline
\end{tabular}




\section{References}

1. J. Mathieu, P. Yu, P. Zuo, M. L. B. Da Silva, P. J. J. Alvarez, Acc. Chem. Res. 52, 849 (2019) DOI: 10.1021/acs.accounts.8b00576

2. L. Sabliy, Y. Kuzminskiy, V. Zhukova, M. Kozar, H. Sobczuk, Ecol. Chem. Eng. S 26, 331 (2019) DOI: 10.1515/eces-2019-0023

3. A. W. Alattabi, C. Harris, R. Alkhaddar, A. Alzeyadi, M. Abdulredha, Procedia Eng. (2017), pp. 800-807 DOI: 10.1016/j.proeng.2017.08.010

4. D. F. Boesch, Front. Mar. Sci. 6, (2019) DOI: 10.3389/fmars.2019.00123

5. A. Ilinykh, O. Naschetnikova, E. Migalatiy, Int. Multidiscip. Sci. GeoConference Surv. Geol. Min. Ecol. Manag. SGEM (2018), pp. 609-616 DOI: 10.5593/sgem2018/3.1/S12.079

6. K. A.G., I. Zafiriadis, A. Aivasidis, Compr. Biotechnol. 297 (2019) DOI: 10.1016/B978-0-444-64046-8.00361-

7. Y. Zhao, D. Liu, W. Huang, Y. Yang, M. Ji, L. D. Nghiem, Q. T. Trinh, N. H. Tran, Bioresour. Technol. 288, (2019) DOI: 10.1016/j.biortech.2019.121619

8. T. Kedrova, L. Khisameeva, R. Abitov, IOP Conf. Ser. Mater. Sci. Eng. (2020) DOI: 10.1088/1757-899X/890/1/012152

9. J. T. Bunce, E. Ndam, I. D. Ofiteru, A. Moore, D. W. Graham, Front. Environ. Sci. 6, (2018) DOI: 10.3389/fenvs.2018.00008

10. T. T. Gorbacheva, P. N. Evshin, A. A. Gorbachev, N. A. Artemkina, Water Ecol. 24, 9 (2019) DOI: 10.23968/2305-3488.2019.24.2.9-16

11. X. Xu, S. Ma, H. Jiang, F. Yang, Chemosphere 275, (2021) DOI: 10.1016/j.chemosphere.2021.130094

12. I. Sarbu and A. Filip, Int. Multidiscip. Sci. GeoConference Surv. Geol. Min. Ecol. Manag. SGEM (2017), pp. 277-284 DOI: 10.5593/sgem2017/51/S20.074

13. E. Neverova-Dziopak, E3S Web Conf. (2018) DOI: 10.1051/e3sconf/20184500056

14. V. I. BAZHENOV, A. N. EPOV, I. A. NOSKOVA, WATER SUPPLY Sanit. Tech. 62 (2014)

15. K. Jóźwiakowski, P. Bugajski, K. Kurek, M. de Fátima Nunes de Carvalho, M. A. A. Almeida, T. Siwiec, G. Borowski, W. Czekała, J. Dach, M. Gajewska, Sep. Purif. Technol. 202, 216 (2018) DOI: 10.1016/j.seppur.2018.03.058

16. A. Busarev, R. Abitov, A. Selyugin, IOP Conf. Ser. Mater. Sci. Eng. (2020) DOI: $10.1088 / 1757-899 X / 890 / 1 / 012149$

17. I. Sheshegova and A. Busarev, IOP Conf. Ser. Mater. Sci. Eng. (2020) DOI: $10.1088 / 1757-899 X / 890 / 1 / 012155$

18. H. Ma, Y. Xue, Y. Zhang, T. Kobayashi, K. Kubota, Y.-Y. Li, Water Res. 172, (2020) DOI: $10.1016 /$ j.watres.2020.115510

19. G. T. Ambrosova, E. N. Matyushenko, N. V. Sineeva, Water Ecol. 2017, 13 (2017) DOI: $10.23968 / 2305-3488.2017 .22 .4 .13-25$

20. G. Sin and R. Al, Npj Clean Water 4, (2021) DOI: 10.1038/s41545-021-00106-5

21. Standard ATV-DVWK-A 131E, Dimensions of Single-Stage Activated Sludge Plants (2000)

22. J. Drewnowski, B. Szeląg, L. Xie, X. Lu, M. Ganesapillai, C. K. Deb, J. SzulzykCieplak, G. Lagód, Molecules 25, (2020) DOI: 10.3390/molecules25040929

23. M. Makowska and A. Sowinska, Desalin. Water Treat. 206, 22 (2020) DOI: 10.5004/dwt.2020.26158

24. E. Płuciennik-Koropczuk and S. Myszograj, Desalin. Water Treat. 186, 334 (2020) DOI: $10.5004 /$ dwt.2020.25383

25. J. Drewnowski, A. Remiszewska-Skwarek, S. Fudala-Ksiazek, A. Luczkiewicz, S. Kumari, F. Bux, J. Environ. Sci. Heal. - Part A Toxic/Hazardous Subst. Environ. Eng. 
54, 736 (2019) DOI: 10.1080/10934529.2019.159253

26. O. V. Kharkina, Efficient Operation and Calculation of Biological Wastewater Treatment Plants (2015)

27. Y. M. Meshangisser, Retechnologization of Wastewater Treatment Plants (2012) 